J. Amer. Soc. Hort. Sci. 117(6):930-933. 1992.

\title{
Storage Atmospheres Influence Chilling Injury and Chilling Injury-induced Changes in Cell Wall Polysaccharides of Cucumber
}

\author{
M. Darlene Mercer ${ }^{1}$ and Doyle A. Smittle ${ }^{2}$ \\ Department of Horticulture, University of Georgia, Tifton, GA 31794 \\ Additional index words. pectins, high $\mathrm{CO}_{2}$, low $\mathrm{O}_{2}$, Cucumis sativis, controlled atmosphere storage
}

\begin{abstract}
Gemini II' cucumber (Cucumis sativus L.) fruits were stored for 2, 4, or 6 days at 5 and $6 \mathrm{C}$ in 1989 and for 5 days at $\mathrm{SC}$ or 10 days at $3 \mathrm{C}$ in 1990. Chilling injury (CI) symptoms were rated after 2 to 4 days at 25C. Cell wall polysaccharide concentrations in the peels and in injured and noninjured portions of the peels were determined only in 1990. High $\mathrm{CO}_{2}$ and low $\mathrm{O}_{2}$ delayed the onset of $\mathrm{CI}$ symptoms, but did not prevent symptom development. Chilling injury symptoms increased with longer exposure to chilling temperatures. Solubilization of cell wall polysaccharides was associated with development of CI symptoms. Variations in low methoxyl pectinates accounted for $70 \%$ of the variation in CI.
\end{abstract}

Chilling injury (CI) is the physiological damage that is induced in tissues when they are exposed to low but nonfreezing temperatures. About one-third of all fruits and vegetables in the U.S. market are susceptible to CI (Wang, 1989). Internal symptoms such as leakage of ions across membranes, changes in membrane fluidity, cessation of cytoplasmic streaming, and inhibition of electron transport (Lyons, 1973) lead to the visible CI symptoms of pitting, discoloration, water-soaking, internal browning, uneven ripening, off-flavor, tissue breakdown, and invasion by postharvest pathogens (Saltveit and Morris, 1990; Wang, 1982). The severity of CI symptoms has often been reduced, but not totally eliminated by prestorage temperature conditioning (Apeland, 1966), intermittent warming (Kader and Morris, 1975; Wang and Baker, 1979), humidity manipulation (Morris and Platenius, 1938), chemical treatments (SchiffmanNadel et al., 1975), waxes (Morris and Platenius, 1938), prestorage atmospheric treatment (Wills et al., 1979), and controlled atmosphere storage (Eaks, 1956).

CI consists of a primary stage and a secondary stage (Raison and Orr, 1990). The primary stage of chilling injury results in an increase in cytoplasmic $\mathrm{Ca}$, a conformational change of a regulatory protein, changes in the cytoskeleton, or an alteration of membrane lipids. Lyons and Raison (1970) suggested that an alteration in the state of membrane lipids from a liquidcrystalline state to a gel state preceded other processes exhibited in the secondary stage (Lyons et al., 1979). Membranes with highly unsaturated fatty acids tolerate lower storage temperatures than tissues with more saturated fatty acids (Markhart, 1986). Lipid peroxidation may influence CI (Simon, 1974; Thompson, 1984), but the exact relationship between lipid peroxidation and CI has not been identified. CI symptoms were reduced by antioxidants that increase the unsaturation of fatty acids (Wang and Baker, 1979).

The tissue breakdown that occurs in the secondary stage of CI may result from breakdown of cell walls. The cell wall support system has not been completely defined, but the idea of cellulose, hemicellulose, pectin, and glycoprotein covalently

\footnotetext{
Received for publication 10 June 1991. Accepted for publication 28 June 1992. Supported by state and Hatch Act funds allocated to the Georgia Agricultural Experiment Stations. The cost of publishing this paper was defrayed in part by the payment of page charges. Under postal regulations, this paper therefore must be hereby marked advertisement solely to indicate this fact.

'Graduate Student.

${ }^{2}$ Professor of Horticulture.
}

joined to form a mesh network has been accepted (McNeil et al., 1984). Fukushima (1978) suggested that chilling broke the plasmalemma of sieve tubes and that the subsequent pectin demethylation caused more rigid cell walls. Chilled cucumber fruits showed an increase in the hot-water insoluble pectin fractions and a decrease in the hot-water soluble pectic fractions (Fukushima and Yamazaki, 1978). However, results from later research do not support the association of decreased pectin solubility with CI. The ethylene precursor 1-aminocylcopropane-1-carboxylic acid (ACC) increases in many plant tissue before CI symptom expression (Wang, 1982). Ethylene increased polygalacturonase (EC 3.2.1.15) activity and cell wall polysaccharide digestion (Elkashif and Huber, 1988). Increased galacturonic acid, a product of polygalacturonase activity on cell wall polysaccharides, accompanied CI development of cucumber (Gross and Wang, 1984).

This research was initiated to establish the cell wall polysaccharide changes associated with CI of cucumber and to examine the influence of storage atmospheres on development of CI. The relationship of CI to cell wall components were further refined by determining the concentrations of cell wall polysaccarides in chilling injured and noninjured portions of the peel of the same cucumber fruits.

\section{Materials and Methods}

Gemini II cucumber fruits were stored at $5 \pm 1 \mathrm{C}$ for Expt. 1 and at $6 \pm 1 \mathrm{C}$ for Expt. 2. Fruits for both experiments were harvested from the same area of a commercial field on 7 and 14 July, 1989, respectively. The fruits were washed, air dried, and three replications of four-fruit samples were randomly selected, weighed, and placed in 20-liter polyethylene chambers. The chambers were attached to a flowmeter-controlled, flowthrough system and flushed at $100 \mathrm{ml} \cdot \mathrm{min}^{-1}$ with humidified atmospheres of $\left(\% \mathrm{CO}_{2}-\% \mathrm{O}_{2}\right)$ O-20, 5-20, 10-20, 5-5, and 105. The balance of the atmosphere was $\mathrm{N}$ in all cases. A flow of $500 \mathrm{ml} \cdot \mathrm{min}^{-1}$ was used to rapidly establish the atmospheres. Atmospheres were passed through two Erlenmeyer flasks containing $800 \mathrm{ml}$ of water each to maintain the relative humidity near saturation. Gas concentrations were monitored daily using a Fisher-Hamilton Gas Partitioner (Fisher Scientific, Pittsburgh).

After 2, 4, or 6 days, chambers were removed from the flow-

$\overline{\text { Abbreviation: }} \mathrm{CI}$, chilling injury. 
through system. The fruits were weighed, and each fruit was evaluated for $\mathrm{CI}$ using a scale of 1 to 5 , based on the percentage of the surface that showed CI: $1=$ no visible CI symptoms, 2 $=\operatorname{slight}(1 \%$ to $10 \%), 3=\operatorname{moderate}(11 \%$ to $25 \%), 4=$ severe $(26 \%$ to $50 \%), 5=$ very severe $(>50 \%)$. Average CI rating for all fruits of a sample was calculated and these data were used for statistical analyses.

Weight loss and CI data were analyzed by ANOVA and regression (SAS, 1982). Data for CI after 2 and 4 days of development at $25 \mathrm{C}$ were analyzed separately. The design within each CI development period was a randomized complete block with three replications of factorial combinations of three cold storage durations and five cold storage atmospheres.

In 1990, 'Gemini II' cucumber were stored at $5 \pm 1 \mathrm{C}$ for Expt. 3 and at $3 \pm 1 \mathrm{C}$ for Expt. 4. Fruits for Expt. 3 were harvested from a commercial field on 2 July, washed, air dried, and three replicates of five-fruit samples were weighed, placed in 20-liter polyethylene chambers, and stored five days at $5 \pm$ $1 \mathrm{C}$ in flow-through, humidified atmospheres of air or $5 \% \mathrm{CO}_{2}$, $5 \% \mathrm{O}_{2}, 90 \% \mathrm{~N}_{2}(\mathrm{CA})$. For Expt. 4, cucumbers from the same area of the field were harvested on 6 July, washed, air dried, and three replicates of five-fruit samples were kept at $3 \pm 1 \mathrm{C}$ for 10 days in air or CA. Fruits of Expt. 3 and Expt. 4 were either evaluated upon removal from cold storage or were kept in air for 3 days at $25 \mathrm{C}$. Nonchilled fruits were also kept for 0 and 3 days at $25 \mathrm{C}$ before their evaluation of $\mathrm{CI}$ symptoms and determination of cell wall polysaccharides.

After CI evaluation as in 1989, cucumber fruits were peeled to a depth of $1.5 \mathrm{~mm}$, and the peels were blended for $5 \mathrm{~min}$ with water equal to twice the peel weight. Blended samples were frozen at $-10 \mathrm{C}$ for eventual cell wall polysacchride analyses. For these analyses, a 5-g aliquot of the thawed sample was weighed into a centrifuge tube. Cell wall polysaccharides were extracted using procedures described by Sistrunk (1956). Pectic components were analyzed as anhydrogalacturonic acid (Dietz and Rouse, 1953). Sugar, starch, hemicellulose, and cellulose concentrations were determined by the method of Dubois et al. (1956).

Cell wall polysaccharide and CI data were subjected to analysis of variance (ANOVA) and regression analyses (SAS, 1982). Relationships among CI and cell wall polysaccharides were determined by simple and multiple correlation regression analyses using the general linear models procedure. Multiple linear regression using the stepwise technique (SAS, 1982) was used to describe the relationships between $\mathrm{CI}$ ratings and cell wall polysaccharides.

For cell wall polysaccharide determination in chilling injured and noninjured portions of the same cucumber fruits in 1990 , 'Gemini II' cucumber fruits were stored for 10 days at $3 \mathrm{C}$ followed by 3 days at $25 \mathrm{C}$. Four replicates of tissues from injured and noninjured areas of the cucumber peels were removed, weighed, blended, and frozen for later cell wall polysaccharide analyses. Cell wall polysaccharide concentrations were analyzed as described earlier, and data were analyzed by ANOVA (SAS, 1982).

\section{Results and Discussion}

The CI symptoms increased with storage at 5 and 6C (Table 1). CI was slight after 2 days, slight to severe after 4 days, and severe to very severe after 6 days of storage at 5 and $6 \mathrm{C}$ followed by 2 days at 25C. CI symptoms were more severe after 4 days than after 2 days at $25 \mathrm{C}$. These results agree with a
Table 1. Effect of storage at $5 \pm 1 \mathrm{C}$ (Expt. 1) or at $6 \pm 1 \mathrm{C}$ (Expt. 2) and duration on storge CI symptoms of 'Gemini II' cucumbers after 2 or 4 days of postchilling holding in air at 25C (1989).

\begin{tabular}{|c|c|c|}
\hline \multirow{2}{*}{$\begin{array}{l}\text { Chilling duration } \\
\text { (days) }\end{array}$} & \multicolumn{2}{|c|}{$\begin{array}{l}\mathrm{Cl} \text { development at } 25 \mathrm{C} \\
\text { (CI symptom rating })\end{array}$} \\
\hline & 2 days & 4 days \\
\hline \multicolumn{3}{|l|}{ Expt. 1} \\
\hline 2 & 1.4 & 1.7 \\
\hline 4 & 3.0 & 3.8 \\
\hline $\begin{array}{c}6 \\
\text { Significance }\end{array}$ & $\mathrm{L}^{*} \mathrm{Q} * *$ & $\mathrm{~L}^{*} \mathrm{Q} * *$ \\
\hline \multicolumn{3}{|l|}{ Expt. 2} \\
\hline 2 & 1.1 & 1.4 \\
\hline 4 & 1.7 & 3.4 \\
\hline 6 & 4.3 & $\mathrm{~L} * * \mathrm{Q} * *$ \\
\hline
\end{tabular}

${ }^{2} \mathrm{CI}$ rating scale: $1=$ none, $2=$ slight $(1 \%$ to $10 \%$ of surface affected $)$, $3=$ moderate $(11 \%$ to $25 \%$ of surface affected $), 4=$ severe $(26 \%$ to $50 \%$ of surface affected), $5=$ very severe $(>50 \%$ of surface affected). ${ }^{y}$ Linear $(\mathrm{L})$ and Quadratic $(\mathrm{Q})$ responses significant at $P=0.05(*)$ or $P=0.01 \quad(* *)$.

Table 2. Effect of storage atmosphere on CI symptoms of 'Gemini II' cucumbers stored 2 to 6 days at $6 \mathrm{C}$ in the atmosphere indicated and then 2 or 4 days in air at 25C (1989, Expt. 2).

\begin{tabular}{lll}
\hline & \multicolumn{2}{c}{$\begin{array}{c}\text { CI development at } 25 \mathrm{C} \\
\text { (CI symptom rating })\end{array}$} \\
\cline { 2 - 3 } $\begin{array}{c}\text { Storage atmospheres } \\
\left(\% \mathrm{CO}_{2}-\% \mathrm{O}_{2}\right)\end{array}$ & 2 days & 4 days \\
\hline $0-20$ & $2.6 \mathrm{a}^{y}$ & $3.2 \mathrm{a}$ \\
$5-20$ & $2.5 \mathrm{ab}$ & $3.4 \mathrm{a}$ \\
$10-20$ & $2.4 \mathrm{bc}$ & $3.2 \mathrm{a}$ \\
$10-5$ & $2.2 \mathrm{c}$ & $3.0 \mathrm{ab}$ \\
$5-5$ & $2.1 \mathrm{c}$ & $2.7 \mathrm{~b}$ \\
\hline
\end{tabular}

${ }^{2} \mathrm{CI}$ rating scale: $1=$ none, $2=$ slight $(1 \%$ to $10 \%$ of surface affected $)$, $3=$ moderate $(11 \%$ to $25 \%$ of surface affected), $4=$ severe $(26 \%$ to $50 \%$ of surface affected), $5=$ very severe $(>50 \%$ of surface affected). 'Mean separation within holding periods by Duncan's multiple range test $P=0.05$ ).

previous report (Eaks, 1956) that CI symptoms of cucumbers increased with longer storage and lower temperatures.

Storage atmospheres did not affect development of CI symptoms when cucumber fruits were stored at 5C (data not shown). The average CI symptoms of the cucumbers were moderate (rating 2.6-3.1) after 2 days at $25 \mathrm{C}$ and moderate to severe (rating 3.2-3.5) after 4 days at $25 \mathrm{C}$.

In contrast, cucumber fruits in Expt. 2, which were stored at 6C, showed less CI when stored in 10-5 or 5-5 atmospheres than in $0-20$ or 5-20 atmospheres after a subsequent 2 days in air at 25C (Table 2). These data, suggesting less CI susceptibility or symptom expression with low $\mathrm{O}_{2}$ atmosphere storage, agree with results of an earlier report (Apeland, 1961). The lower degree of CI when cucumbers were held in 10-20 than in 0-20 atmosphere suggest that high $\mathrm{CO}_{2}$ slightly reduced CI of these cucumbers. These results are in conflict with the earlier research by Eaks (1956) who reported that CI increased with increasing $\mathrm{CO}_{2}$ levels. After 4 days of CI development, CI was reduced only when cucumbers were stored in $5 \% \quad \mathrm{CO}_{2}$ and $5 \%$ $\mathrm{O}_{2}$.

Cucumber fruits of Expt. 3 did not express CI symptoms or show significant changes of cell wall polysaccharides (data not shown). The factors contributing to the lower CI susceptibility in 1990 than in 1989 were not determined. Increased CI sus- 
ceptibility of cucumber fruits was observed when fruits were harvested immediately after rainfall (Nakamura et al., 1985). Climatological data suggest that cucumber fruits were exposed to more severe preharvest water stress conditions in 1990 than in 1989.

Strong interactions occurred between chilling treatments and duration of exposure to $25 \mathrm{C}$ for $\mathrm{CI}$ development and cell wall polysaccharides; therefore, data are presented only for the interactions (Table 3). Symptoms of CI were not evident upon removal of cucumbers from 10 days of storage at 3C, but after 3 days at $25 \mathrm{C}$, cucumbers stored air exhibited moderate CI symptoms, while those stored in CA exhibited only slight symptoms. Although CI symptoms were more severe with storage for 5 days at $5 \mathrm{C}$ in 1989 than with storage for 10 days at $3 \mathrm{C}$ in 1990 , storage in $5 \% \quad \mathrm{CO}_{2}$ and $5 \% \mathrm{O}_{2}$ reduced the severity of $\mathrm{CI}$ symptoms both years.

Storage conditions that resulted in more severe CI also resulted in increased concentrations of the more soluble pectic components (Table 3). Cell wall polysaccharide concentrations had not been affected by storage atmosphere when the fruit was removed from cold storage, but after an additional 3 days at $25 \mathrm{C}$, the concentrations of pectinic acid (WSP), which is water soluble, and low methoxyl pectinates (CSP) had increased and concentrations of less soluble high methoxyl pectinates (PP) had decreased. These results contradict an earlier report (Fukushima and Yamazaki, 1978) that the less soluble pectic components increased and the more soluble pectic components decreased with CI. However, our data agree with the report by Gross and Wang (1984) that tissue breakdown results in increased concentrations of more soluble pectic components of cell walls.

Hemicellulose and cellulose were not influenced by storage conditions (data not shown); their respective concentrations averaged $1.08 \mathrm{mg} \cdot \mathrm{g}^{-1}$ and $13.5 \mathrm{mg} \cdot \mathrm{g}^{-1}$ fresh weight.

Simple correlation analyses of 1990 data showed significant positive relationships between $\mathrm{CI}$ and concentrations of pectinic acid $(r=+0.78)$ and low methoxyl pectinates $(r=+0.83)$, and a significant negative relationship between the $\mathrm{CI}$ and the concentration high methoxyl pectinates $(r=-0.55)$ of cucumber peels. Hemicellulose and cellulose were not significantly related to CI. Significant negative relationships also occurred between the concentrations of high methoxyl pectinates and the

Table 3. Influence of 10 days of storage at $3 \mathrm{C}$ in air or $5 \% \mathrm{CO}$, and $5 \% \mathrm{O}_{2}(\mathrm{CA})$ on $\mathrm{CI}$ and cell wall polysaccharides of 'Gemini II' cucumbers before and after holding in air for 3 days at 25C (Expt. $4)$.

\begin{tabular}{|c|c|c|c|c|c|}
\hline \multirow{2}{*}{$\begin{array}{l}\text { Chilling } \\
\text { treatments }\end{array}$} & \multirow{2}{*}{$\begin{array}{c}\text { Days at } \\
25^{\circ} \mathrm{C}\end{array}$} & \multicolumn{4}{|c|}{ Cell wall polysaccharide $\left(\mathrm{mg} \cdot \mathrm{g}^{-1}\right)^{2}$} \\
\hline & & $\mathrm{CI}^{y}$ & WSP & CSP & PP \\
\hline \multirow[t]{2}{*}{ Nonchilled } & 0 & 1.0 & 0.44 & 1.65 & 1.37 \\
\hline & 3 & 1.0 & 0.43 & 1.76 & 1.31 \\
\hline \multirow[t]{2}{*}{ Air chilled } & 0 & 1.1 & 0.44 & 2.19 & 1.46 \\
\hline & 3 & 3.1 & 0.92 & 3.80 & 0.77 \\
\hline \multirow[t]{2}{*}{ CA chilled } & $\overline{0}$ & 1.0 & 0.44 & 1.84 & 1.23 \\
\hline & 3 & 2.1 & 0.59 & 3.84 & 1.03 \\
\hline
\end{tabular}

${ }^{2}$ Cell wall polysaccharides of fresh peel tissues are pectinic acid (WSP), low methoxyl $\mathrm{Ca}$ and $\mathrm{Mg}$ pectinates (CSP), and high methoxyl $\mathrm{Ca}$ and $\mathrm{Mg}$ pectinates (PP).

${ }^{y} \mathrm{CI}$ rating scale: $1=$ none, $2=$ slight $(1 \%$ to $10 \%$ of surface affected $)$, $3=$ moderate $(11 \%$ to $25 \%$ of surface affected $), 4=$ severe $(26 \%$ to $50 \%$ of surface affected), $5=$ very severe (> 50\% of surface affected). ${ }^{\times}$Chilling treatments $\times$days at $25 \mathrm{C}$ interactions significant at $P=$ $0.05(*)$ or $P=0.01(* *)$. more soluble pectinic acid $(r=-0.35)$ and low methoxyl pectinate $(r=-0.41)$ pectic components. These relationships of CI to pectic components and the positive and negative relationships among the pectic fractions further indicate that CI increased the solubilization of cell wall polysaccharide since the correlations of CI to the more soluble pectic components were positive and correlation of CI to the less soluble pectic component were negative.

Variations in the concentration of low methoxyl pectinates accounted for $70 \%$ of the variation in CI as determined by multiple linear regression (Table 4). Inclusion of pectinic acid, expressed as a percent of the total pectin, was significant at $P=$ 0.05 and increased the $R^{2}$ value to 0.81 . Inclusion of hemicellulose expressed as a percentage of the sum of the hemicellulose and the cellulose fractions increased the $R^{2}$ value only slightly (nonsignificant at $P=0.05$ ).

The sugar and starch concentrations were similar in injured and noninjured tissues, but cell wall polysaccharides of injured and noninjured areas of cucumber peels differed (Fig. 1). The chilling injured portions of the cucumber peels had higher concentrations of pectinic acid and low methoxyl pectinates and lower concentrations of high methoxyl pectinates than the noninjured portions. Although the correlation analyses did not show significant relationships between CI and hemicellulose and cellulose in entire peels of cucumber fruits, the concentration of hemicellulose was higher and the concentration of cellulose was lower in the injured portion than in the noninjured portion of the same cucumber peels (Fig. 1)

These results show that $\mathrm{CI}$ increased with longer exposure to

Table 4. Stepwise regression to describe the relationships of CI ratings and cell wall polysaccharide concentrations ${ }^{2}$ (1990 data).

\begin{tabular}{lc}
\hline \hline Regression & $R^{2}$ \\
\hline $\mathrm{CI}=0.001+0.637 \mathrm{CSP}$ & 0.70 \\
$\mathrm{CI}=-0.243+0.666 \mathrm{CSP}+0.009 \mathrm{P} 1$ & 0.81 \\
$\mathrm{CI}=-0.091+0.711 \mathrm{CSP}+0.008 \mathrm{P} 1-0.003 \mathrm{HCC}$ & 0.83 \\
\hline
\end{tabular}

${ }^{2}$ Cell wall polysaccharides are low methoxyl pectinates (CSP), pectinic acid expressed as a percent of total pectin, and hemicellulose expressed as a percentage of the sum of the hemicellulose and cellulose fractions (HCC).

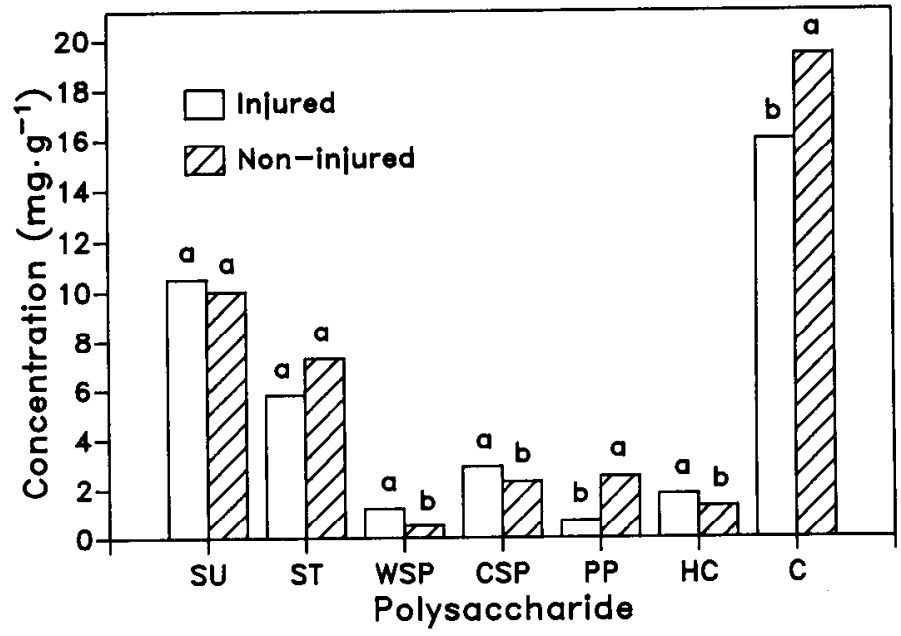

Fig. 1. Sugar (SU), starch (ST), pectinic acid (WSP), low methoxyl pectinates (CSP), high methoxyl pectinates (PP), hemicellulose (HC), and cellulose (C) concentrations (fresh weight basis) of chilling injured and noninjured portions of peels of the same cucumbers. 
chilling temperatures and that the combination of high $\mathrm{CO}_{2}$ and low $\mathrm{O}_{2}$ in the atmosphere reduced CI symptom severity, but did not prevent CI symptom development. The data also show that the development of CI symptoms is associated with solubilization of pectic components of cell walls. Although the more soluble pectinic acid and the low methoxyl pectinate fractions increased and the less soluble high methoxyl pectinate fraction decreased, variations in concentrations of low methoxyl pectinates accounted for $70 \%$ of the variation in CI.

\section{Literature Cited}

Apeland, J. 1966. Factors effecting the sensitivity of cucumbers to chilling temperatures. Bul. Intl. Inst. Refrig., Annex 1. 46:325333.

Dietz, J.H. and A.H. Rouse. 1953. A rapid method of estimating pectic substances. Food Res. 18:169-177.

Dubois, M., K.A. Gilles, J.K. Hamilton, P.A. Reners, and F. Smith. 1956. Calorimetric method of determining sugars and related substances. Anal. Chem. 28:350-356.

Eaks, I.L. 1956. Effects of modified atmospheres on cucumbers at chilling and nonchilling temperatures. Proc. Amer. Soc. Hort. Sci. 67:473-478

Elkashif, M.E. and D.J. Huber. 1988. Electrolyte leakage, firmness, and scanning electron microscopic studies of watermelon fruit treated with ethylene. J. Amer. Soc. Hort. Sci. 113:378-381.

Fukushima, T. 1978. Chilling injury in cucumber fruits. VI. The mechanism of pectin de-methylation. Scientia Hort. 9:215-226.

Fukushima, T. and M. Yamazaki. 1978. Chilling injury in cucumbers V. Polysaccharide changes in cell walls. Scientia Hort. 8:219-227.

Gross, K. and C.Y. Wang. 1984. Compositional changes in cell wall polysaccharides from chilled and nonchilled cucumber fruit. Phytochemistry 23:1575-1578.

Kader, A.A. and L.L. Morris. 1975. Amelioration of chilling injury symptoms on tomato fruits. HortScience 10:324.

Lyons, J.M. 1973. Chilling injury in plants. Annu. Rev. Plant Physiol. 24:445-466.

Lyons, J.M. and J.K. Raison. 1970. Oxidative activity of mitochondria isolated from plant tissues sensitive and resistant to chilling injury. Plant Physiol. 45:386-389.

Lyons, J.M., D. Graham, and J.K. Raison. 1979. Low Temperature Stress in Crop Plants: The role of the membrane. Academic Press, New York.
Markhart, A.H. 1986. Chilling injury: A review of possible causes. HortScience 21:1329-1333.

McNeil, M., A.G. Darvill, S.C. Fry, and P. Albersheim. 1984. Structure and function of the primary cell walls of plants. Annu. Rev. Biochem. 53:625-663.

Morris, L.L. and H. Platenius. 1938. Low temperature injury to certain vegetables after harvest. Proc. Amer. Soc. Hort. Sci. 36:609-613.

Nakamura, R., A. Inaba, and T. Ito. 1985. Effect of cultivating conditions and postharvest stepwise cooling on the chilling sensitivity of eggplant and cucumber fruits. Sci. Rpt. Faculty Agr. 66:19-29 (in Japanese; English summary).

Raison, J.K. and G.R. Orr. 1990. Proposals for a better understanding of the molecular basis of chilling injury, p. 145-164. In: C.Y. Wang (ed.). Chilling injury of horticultural crops. CRC Press, Boca Raton, Fla.

Saltveit, M.E. and L.L. Morris 1990. Overview of chilling injury of horticultural crops, p. 3-17. In: C.Y. Wang (ed.). Chilling injury of horticultural crops. CRC Press, Boca Raton, Fla.

SAS Institute. 1982. SAS user's guide: Statistics. 1982 (ed.). SAS Institute, Gary, N.C.

Schiffman-Nadel, M., E. Chalutz, T. Waks, and M. Dagan. 1975. Reduction of chilling injury in grapefruit by thiabendazole and benomyl during long-term storage. J. Amer. Soc. Hort. Sci. 100:270272.

Simon, E.W. 1974. Phospholipids and plant membrane permeability. New Phytol. 73:377-420.

Sistrunk, W.A. 1956. Effect of storage and temperature of fresh snap beans on chemical composition of the canned product. Proc. Amer. Soc. Hort. Sci. 86:380-386.

Thompson, J.E. 1984. Physical changes in the membranes of senescing and environmentally stressed plant tissues, p. 85-108. In: M. Shinitzky (ed.). Physiology of membrane fluidity, vol. 2. CRC Press, Boca Raton, Fla.

Wang, C.Y. 1982. Physiological and biochemical responses of plants to chilling stress. HortScience 17:173-186.

Wang, C.Y. 1989. Chilling injury of fruits and vegetables. Food Rev. Intl. 5:209-236.

Wang, C.Y. and J.E. Baker. 1979. Effects of two free radical scavengers and intermittent warming on chilling injury and polar lipid composition of cucumber and sweet pepper fruits. Plant Cell Physiol. 20:243-251.

Wills, R.B.H., P. Wimalasiri, and K.J. Scott. 1979. Short pre-storage exposures to high carbon dioxide or low oxygen atmospheres for the storage of some vegetables. HortScience 14:528-530. 